\title{
APPELLATE REVIEW FOR INDIGENT CRIMINAL DEFENDANTS IN THE FEDERAL COURTS
}

Recent Supreme Court decisions have created considerable uncertainty concerning the limits which may properly be imposed upon the opportunity of indigent defendants convicted in the federal courts to obtain appellate review in forma pauperis. In Johnson v. United States, ${ }^{1}$ the Court held it improper for the court of appeals to deny a petition for leave to appeal in forma pauperis where such denial resulted from a hearing at which the indigent had been accorded neither the aid of counsel nor the use of a trial transcript.2 Subsequently, in Farley $v$. United States, ${ }^{3}$ the denial of a transcript led to a similar holding even though the indigent had been represented by counsel at the preliminary hearing. ${ }^{4}$ Finally, in Ellis v. United States, ${ }^{5}$ the Court again refused to sanction a denial of leave to appeal in forma pauperis, this time premising its decision upon the inadequacy of the indigent's counsel plus the fact that the allegations in the petition for leave to appeal were not plainly frivolous. ${ }^{6}$

1352 U.S. 565 (1957), vacating the judgment in United States v. Johnson, 238 F.2d 565 (C.A.2d, 1957).

2 The Court stated (in part), "Moreover, a Court of Appeals must, under Johnson v. Zerbst, 304 U.S. 458, afford one who challenges that certification the aid of counsel unless he insists on being his own. Finally, either the defendant or his assigned counsel must be enabled to show that the grounds for seeking an appeal from the judgment of conviction are not frivolous and do not justify a finding that the appeal is not sought in good faith. ..." Id., at 566.

3354 U.S. 521 (1957), vacating the judgment in United States v. Farley, 242 F.2d 338 (C.A.2d, 1957). See also United States v. Farley, 238 F.2d 575 (C.A.2d, 1956).

${ }^{4}$ The Court stated (in part), "Before his [the indigent petitioner's] allegation of errors can be accurately evaluated, however, to ascertain if they do have any merit he should be furnished with a transcript of the trial record-unless counsel can agree on a statement of the relevant facts or some other means are devised to make the minutes of the trial available to petitionerso that he has the opportunity to substantiate his allegations and point out their significance and so that they can be appraised on a dependable record. ..." Id., at 522-23.

5356 U.S. 674 (1958), vacating the judgment in Ellis v. United States, 249 F.2d 478 (App.D.C., 1958).

${ }^{6}$ This time the Court did not hold that the reviewing court would need a record in order to give the indigent a fair hearing. Rather the Court stated (in part), "In the absence of some evident improper motive, the applicant's good faith is established by the presentation of any issue that is not plainly frivolous. Farley v. United States, 254 U.S. 521. The good-faith test must not be converted into a requirement of a preliminary showing of any particular degree of merit. Unless the issues raised are so frivolous that the appeal would be dismissed in the case of a nonindigent litigant, Fed. Rules Crim. Proc. 39(a), the request of an indigent for leave to appeal in forma pauperis must be allowed." Id., at 674-75.

The rule of the Johnson and Farley cases may be read as a rigid requirement that indigents must be g!ven transcripts in every case before the court of appeals may decide whether to grant leave to appeal in forma panperis. Some of the lower courts have so understood these cases. Cash v. United States, 261 F.2d 731 (App.D.C., 1958), judgment vacated 357 U.S. 219 (1958); Whitt v. United States, 259 F.2d 158 (App.D.C., 1958); United States v. Mallison, 250 F.2d 792 (C.A.2d, 1957); O'Rourke v. United States, 248 F.2d 812 (C.A.1st, 1957), cert. denied sub. nom. Dewan v. United States, 356 U.S. 922 (1958); Hill v. United States, 248 F.2d 635 (App.D.C., 1957), judgment vacated 356 U.S. 704 (1958); Coleman v. United States, 247 F.2d 799 (App.D.C., 1957); Gomez v. United States, 245 F.2d 346 (C.A.5th, 1957); United 
In each of these cases, the Court disposed of the issues in a brief per curiam opinion. ${ }^{7}$ The uncertainty generated by the absence of explicit reasoning in support of these decisions is aggravated by the ambiguity of the remarks actually made. Considerable disagreement among the lower federal courts as to the proper rationale of these cases has thus arisen and has occasioned doubt as to the present state of the law governing the "sifting" of indigent appeals. ${ }^{8} \mathrm{Al}-$

States v. Ramos, 158 F.Supp. 825 (E.D.N.Y., 1958); United States v. Dudley, 154 F.Supp. 623 (S.D.N.Y., 1957). Insofar as the Ellis case did not require the appellate court to order a free transcript for the indigent, it may indicate somewhat of a retreat from the more rigid Johnson rule that a court of appeals cannot adequately rule on the petition for leave to appeal in forma pathperis unless it has a transcript. Ellis would seem to say that such a ruling can sometimes be properly made without a transcript. Of course, if the ruling on the petition is favorable to the indigent, then a transcript would probably be granted for the actual appeal. But see St. Lawrence v. Clemmer, 260 F.2d 470 (C.A.4th, 1958). However, if the ruling is adverse to the indigent, the appellate court seems to risk reversal if it has not examined the transcript (unless the petition is truly patently frivolous). See Cash v. United States, 261 F.2d 731 (App.D.C., 1958), judgment vacated 357 U.S. 219 (1958). But cf. Young v. United States, 246 F.2d 901 (C.A.8th, 1957), cert. denied 355 U.S. 917 (1958).

${ }^{7}$ The Supreme Court has per curiam vacated other like judgments of the courts of appeals dealing with indigent petitioners. Kitchens v. United States, 358 U.S. 42 (1958) (no lower report found); Hansford v. United States, 351 U.S. 578 (1958) (no lower report found); Cash v. United States, 357 U.S. 219 (1958) (case reported below in 261 F.2d 731 [App.D.C., 1958]); Hill v. United States, 356 U.S. 704 (1958) (case reported below in 248 F.2d 635 [App. D.C., 1957]); Edwards v. United States, 355 U.S. 36 (1957) (no lower report found, but decision after remand in 256 F.2d 885 [App. D.C., 1958]); Delbridge v. United States, 354 U.S. 906 (195\%) (no lower report found); cf. United States ex rel. Farnsworth v. Murphy, 358 U.S. 48 (1958) (case reported below in 254 F.2d 438 [C.A.2d, 1958]); Smith v. United States, 358 U.S. 281 (1959) (semble); United States ex rel. Jennings v. Ragen, 358 U.S. 276 (1959) (semble). The ultimate disposition of the Johnson case will be found in $254 \mathrm{~F} .2 \mathrm{~d} 175$ (C.A.2d, 1958), cert. dismissed 357 U.S. 933 (1958).

${ }^{8}$ Some courts seem to have adopted a compromise between the Johnson and Ellis rules. They procure the records and make an independent examination to determine whether to allow the appeal. Application of Dinerstein, 258 F.2d 609 (C.A.9th, 1958); Anderson v. Heinze, 258 F.2d 479 (C.A.9th, 1958), cert. denied 358 U.S. 889 (1958); Woody v. United States, 258 F.2d 535 (C.A.6th, 1957); Hayes v. United States, 258 F.2d 400 (C.A.5th, 1958); Gilpin v. United States, 252 F.2d 685 (C.A.6th, 1958); In re Woods, 249 F.2d 614 (C.A.9th, 1957), cert. denied 356 U.S. 921 (1958); United States ex rel. Rodriguez v. Jackson, 246 F.2d 730 (C.A.2d, 1957); Gomez v. United States, 245 F.2d 346 (C.A.5th, 1957); United States ex rel. Tierney v. Richmond, 245 F.2d 222 (C.A.2d, 1957); Hill v. Settle, 244 F.2d 311 (C.A.8th, 1957); Gershon v. United States, 243 F.2d 527 (C.A.8th, 1957), cert. denied 355 U.S. 873 (1957); Hodge v. Heinze, 165 F.Supp. 726 (N.D.Calif., 1958); Young v. United States, 246 F.2d 901 (C.A.8th, 1957), cert. denied 355 U.S. 917 (1958) (semble). This procedure is clearly more economical than preparing a duplicate record for the indigent to bring to the court, and to a large degree minimizes the possibility of a valid claim of error being kept silent. However, some courts have used this procedure as a device for denying counsel to the indigent. This would seem to controvert the absolute guaranty of counsel announced in the Johnson case. Other courts have attempted to construe the Johnson, Farley and Ellis cases as narrowly as possible. The suggestion has been made that these cases dealt only with direct appeals under Section 1915 and therefore do not apply to other post-conviction procedures. See cases cited in note 16 infra. Another line of distinction has held that collateral attacks upon judgments of conviction (e.g., habeas corpus, coram nobis) are civil rather than criminal in nature and therefore do not fall within the scope of the Sixth Amendment which is understood to be the basis of the Johnson opinion. See cases cited in note 17 inira. In those cases where the facts are identical to those in 
though confusion is to some extent unavoidable in instances such as these, it is submitted that analysis of the issues presented yields some basis for consistent interpretation. It is the purpose of this comment to provide a framework for such interpretation.

\section{I}

The statutory basis for appeals in forma pauperis is Section 1915 of Title 28 of the United States Code. ${ }^{9}$ After setting forth the general rule that any United States court may allow an appeal to be taken in forma pauperis, this section provides that, "[a]n appeal may not be taken ... if the trial court certifies in writing that it is not taken in good faith."10 Prior to the Johnson case, indigents had rarely managed to avail themselves of the provisions of Section 1915 allowing in forma pauperis appeals. The courts had developed the doctrine that an appeal in forma pauperis was a privilege rather than a right." The term "good

the Johnson case, the courts have accorded the indigent the treatment required by the Supreme Court. See Whitt v. United States, 259 F.2d 158 (App.D.C., 1958); United States v. Mallison, 250 F.2d 792 (C.A.2d, 1957); O'Rourke v. United States, 248 F.2d 812 (C.A.1st, 1957), cert. denied sub. nom. Dewan v. United States, 356 U.S. 922 (1958); Coleman v. United States, 247 F.2d 799 (App.D.C., 1957); Gomez v. United States, 245 F.2d 346 (C.A.5th, 1957); United States v. Ramos, 158 F.Supp. 825 (E.D.N.Y., 1958); United States v. Dudley, 154 F.Supp. 623 (S.D.N.Y., 1957). But see Cash v. United States, 261 F.2d 731 (App.D.C., 1958), judgment vacated 357 U.S. 219 (1958); Hill v. United States, 248 F.2d 635 (App.D.C., 1957), judgment vacated 356 U.S. 704 (1958).

${ }^{2} 62$ Stat. 954 (1948), as amended, 28 U.S.C.A. \$1915 (Supp., 1958).

${ }^{10} 62$ Stat. 954 (1948), as amended, 28 U.S.C.A. \$1915(a) (Supp., 1958). The statute further provides, in subsection (b), that if the appellate court requires, the record will be printed at government expense. In subsection (d), the court is authorized to appoint an attorney for the indigent and to dismiss the case if satisfied that the action is frivolous or malicious. Another statute, 62 Stat. 922 (1951), as amended, 28 U.S.C.A. \$753(f) (1949), provides that the United States will pay for transcripts given to those allowed to sue, defend or appeal in forma pauperis in criminal or habeas corpus proceedings. Originally subsection (b) of Section 1915 included a provision for stenographic transcripts as well as records. The two statutes then seemed to duplicate one another. Cf. Montgomery v. Virginia Stage Lines, 184 F.2d 1000 (App.D.C., 1950); United States v. Carter, 88 F.Supp. 88 (D.D.C., 1950). Consequently, Section 1915 was changed to omit transcripts, 65 Stat. 727 (1948), amending 28 U.S.C.A. $\$ 1915$ (b) and (e) (Supp., 1958). This was done solely to avoid duplication. 1951 U.S. Code Cong. and Admin. Serv. 2578, 2593. Confusion still exists, however, as to the respective scope of each statute. See Whitt v. United States, 259 F.2d 158 (App.D.C., 1958); United States v. Stevens, 224 F.2d 866 (C.A.3d, 1955); Parsell v. United States, 218 F.2d 232 (C.A.5th, 1955); United States v. Ramos, 158 F.Supp. 825 (E.D.N.Y., 1958).

Under Section 753(f), fees for transcripts furnished in criminal or habeas corpus proceedings are to be paid out of United States funds, but fees for transcripts in other proceedings are to be paid by the United States only if the trial judge certifies that the appeal is not frivolous, but presents a substantial question. By reading the good-faith requirement of Section 1915(a) into this statute, the courts appear to have effectively abolished the distinction between criminal and habeas corpus appeals on the one hand, and other types of appeals involving in forma pauperis procedures. See, e.g., In the matter of Mitchell, 230 F.2d 786 (C.A.9th, 1955); Wheeler v. Reid, 175 F.2d 829 (App.D.C., 1948).

11 Gomez v. United States, 245 F.2d 346 (C.A.5th, 1957); Parsell v. United States, 218 F.2d 232 (C.A.5th, 1955); Morris v. Igoe, 209 F.2d 108 (C.A.7th, 1953); Taylor v. Steele, 191 
faith" was interpreted as requiring an initial showing of merit by the indigent, ${ }^{12}$ and if the indigent failed to convince the trial court that his appeal did have merit, the appellate court would allow an appeal only if the indigent could convince them that the certificate of bad faith was unwarranted. ${ }^{13}$ In the absence of an affirmative showing to the contrary, the certificate of the trial judge thus was controlling. ${ }^{14}$ Since the indigent seeking to overturn the certificate was not

F.2d 852 (C.A.8th, 1951); Hodge v. Heinze, 165 F.Supp. 726 (N.D.Calif., 1958). However, the indigent has the right to request leave to appeal in forma pauperis, and the district court must entertain his petition to this effect. Steffler v. United States, 319 U.S. 38 (1943); United States ex rel. Morris v. Radio Station WENR, 209 F.2d 105 (C.A.7th, 1953).

12 Cash v. United States, 261 F.2d 731 (App.D.C., 1958), judgment vacated 357 U.S. 219 (1958); United States v. Visconti, 261 F.2d 215 (C.A.2d, 1958); Parsell v. United States, 218 F.2d 232 (C.A.5th, 1955); Wheeler v. Reid, 175 F.2d 829 (App.D.C., 1948); United States v. Durham, 130 F.Supp. 455 (D.D.C., 1955).

${ }^{13}$ Generally the appellate court would not listen to the indigent unless the district court had certified one way or the other. Hayes v. United States, 258 F.2d 400 (C.A.5th, 1958); Elkins v. United Stakes, 250 F.2d 145 (C.A.9th, 1957); United States v. Farley, 238 F.2d 575 (C.A.2d, 1956). Contra: Jordan v. United States District Court for District of Columbia, 233 F.2d 362 (App.D.C., 1956); Gerringer v. United States, 213 F.2d 346 (App.D.C., 1954). See Steffler v. United States, 319 U.S. 38 (1943); United States ex rel. Morris v. Radio Station WENR, 219 F.2d 105 (C.A.7th, 1953).

The order of the District Court denying the petitioner leave to appeal in forma pauperis was not considered an appealable order. Parsell v. United States, 218 F.2d 232 (C.A.5th, 1955); Higgins v. Steele, 195 F.2d 366 (C.A.8th, 1952). Contra: United States ex rel. Morris v. Radio Station WENR, 209 F.2d 105 (C.A.7th, 1953). See Orfield, Criminal Appeals in America 249 (1939). However, since Section 1915(a) says "[a]ny court of the United States may authorize," the courts of appeals would allow the indigent to apply directly to them for leave to appeal in forma panperis. Steffler v. United States, 319 U.S. 38 (1943); Cash v. United States, 261 F.2d 731 (App.D.C., 1958), judgment vacated 357 U.S. 219 (1958); Whitt v. United States, 259 F.2d 158 (App.D.C., 1958); Weber v. United States, 254 F.2d 713 (C.A.8th, 1958); United States v. Mallison, 250 F.2d 792 (C.A.2d, 1957); Briscoe v. United States, 248 F.2d 640 (App.D.C., 1957); Hill v. United States, 248 F.2d 635 (App.D.C., 1957), judgment vacated 356 U.S. 704 (1958); Wheeler v. Reid, 175 F.2d 829 (App.D.C., 1948). For an extensive collection of such cases, see Aid for Indigent Litigants in the Federal Courts, 58 Col. L. Rev. 832 (1958).

Since the Johnson case, some courts have held that this order now is appealable. Anderson v. Heinze, 258 F.2d 479 (C.A.9th, 1958); O'Rourke v. United States, 248 F.2d 812 (C.A.1st, 1957). Contra: Gomez v. United States, 245 F.2d 346 (C.A.5th, 1957). See Qua, Griffin v. Illinois, 25 U. of Chi. L. Rev. 143, 149 (1957). The Effect of Grifin v. Illinois on the States' Administration of the Criminal Law, 25 U. of Chi. L. Rev. 161, 169 (1957). But since the effect of the Supreme Court decisions is to lower the standards at the preliminary hearings or to provide some sort of records for the petitioner at the hearing, the conclusion that this means that the order below deny ing leave to appeal in forma pauperis is now appealable is unwarranted. Insofar as any indigent could go directly to the court of appeals once being denied leave to appeal by the district court, and the court of appeals could, on its own, grant leave to appeal in forma pauperis, the order was always appealable in the sense that the indigent was not remediless after the district court denied his application. This is provided for in Section 1915(a) which allows any court to grant leave to appeal in forma pauperis. Insofar as the indigent can still not get a full transcript for the preliminary hearing, which he would get on an appeal, the order denying leave to appeal in forma panperis by the district court is still not completely appealable.

14 Wells v. United States, 318 U.S. 257 (1943); Weber v. United States, 257 F.2d 585 (C.A.8th, 1958); Weber v. United States, 254 F.2d 713 (C.A.8th, 1958); Gilpin v. United 
accorded the aid of a transcript or counsel, it is not surprising that a substantial number of appeals which may in fact have been meritorious never received adequate appellate review. ${ }^{15}$

\section{II}

Four distinct views have appeared concerning the nature of the changes entailed by the Supreme Court pronouncements in the Johnson, Farley and Ellis cases. At one end of the spectrum is the view that these cases represent nothing more than a new interpretation of Section $1915 .{ }^{16}$ A slightly more expansive view is taken by those courts which discern a rationale based upon the Sixth Amendment in these cases. ${ }^{17}$ The third view is held by those who interpret the Court's decisions as laying down basic tests of fairness in appellate hearings required by the Due Process Clause of the Fifth Amendment. ${ }^{18}$ The fourth view is that these decisions amount to a prohibition of any disparate treatment between indigent and nonindigent appeals. ${ }^{19}$

States, 252 F.2d 685 (C.A.6th, 1958); In re Woods, 249 F.2d 614 (C.A.9th, 1957); O'Rourke v. United States, 248 F.2d 812 (C.A.1st, 1957); Hill v. United States, 248 F.2d 635 (App.D.C., 1957), judgment vacated 356 U.S. 704 (1958); Hill v. Settle, 244 F.2d 311 (C.A.8th, 1957); In the matter of Mitchell, 230 F.2d 786 (C.A.9th, 1955); Higgins v. Steele, 195 F.2d 366 (C.A.8th, 1952); Wheeler v. Reid, 175 F.2d 829 (App.D.C., 1948).

${ }^{15}$ Some courts would demand that the indigent demonstrate the error of the trial judge with a degree of particularity possible only by virtue of the assistance of transcript or counsel, which, of course, the indigent lacked. See, e.g., Gilpin v. United States, 252 F.2d 685 (C.A.6th, 1958); Farley v. United States, 238 F.2d 575 (C.A.2d, 1956), judgment vacated 354 U.S. 521 (1957). Other courts would not review at all if the trial judge certified bad faith. In the matter of Mitchell, 230 F.2d 786 (C.A.9th, 1955); In re Wragg, 95 F.2d 252 (C.A.5th, 1938). In these circumstances, the dissenting opinion of Judge Frank in United States v. Johnson, 238 F.2d 565, 568 (C.A.2d, 1956), seems persuasive: "If, however, the defendant is so destitute that he cannot pay the docket fee, and if the trial judge has signed a certificate of 'bad faith,' then although a reading of the transcript shows clear reversible errors, the federal appellate court is powerless to hear the appeal and thus to rectify the errors. ..." Ironically, if the indigent could demonstrate to the appellate court and thereby succeed in gaining leave to appeal in forma panperis, he would then be given counsel and transcript to aid him on the appeai. However, the aliowance of the appeal did not mean this was done automatically. See St. Lawrence v. Clemmer, 260 F.2d 470 (C.A.4th, 1958).

${ }^{16}$ See the concurring opinion in Cash v. United States, 261 F.2d 731, 739 (App.D.C., 1958), judgment vacated 357 U.S. 219 (1958).

${ }^{17}$ Anderson v. Heinze, 258 F.2d 479 (C.A.9th, 1958), cert. denied 358 U.S. 889 (1958); Gershon v. United States, 243 F.2d 527 (C.A.8th, 1957), cert. denied 355 U.S. 873 (1957); Application of Dinerstein, 258 F.2d 609 (C.A.9th, 1958) (semble); Application of Hodge, 248 F.2d 843 (C.A.9th, 1957) (semble); Young v. United States, 246 F.2d 901 (C.A.8th, 1957), cert. denied 355 U.S. 917 (1958) (semble); Hill v. Settle, 244 F.2d 311 (C.A.8th, 1957) (semble).

${ }^{18}$ Consult Whitt v. United States, 259 F.2d 158 (App.D.C., 1958); United States ex rel. Marcial v. Fay, 247 F.2d 662 (C.A.2d, 1957), cert. denied 355 U.S. 915 (1958); Judge Frank's dissent in United States v. Johnson, 238 F.2d 565, 567 (C.A.2d, 1956).

19 "In these cases the courts denying appeals have failed to notice the discrimination against the poor, resulting from letting the rich appeal as a matter of course while screening the appeals of the poor for 'good faith.' "Willcox and Bloustein, The Griffin Case-Poverty and the Fourteenth Amendment, 43 Cornell L. Q. 1, 21 (1957). See also Orfield, Criminal Appeals in America 179 (1939). 
At the outset it seems possible to rule out the first two of these four views. It would be difficult to interpret all the Supreme Court said in these cases as merely interpretations of a statute. To be sure, the Court did, in the Johnson case, preface its opinion with a citation of Section 1915, but it then proceeded to cite Johnson v. Zerbst, ${ }^{20}$ a case decided on the basis of the Sixth Amendment, ${ }^{21}$ and then concluded its opinion with pronouncements of application too general to be drawn from the statute.22 The opinions in the Farley and Ellis cases offer even less support for a statutory interpretation rationale. ${ }^{23}$

Nor would Section 1915 itself seem capable of sustaining such an interpretation. ${ }^{24}$ The legislative history of this statute indicates rather clearly that Congress did not view the statute as according as much protection to indigents as the Supreme Court required in the Johnson, Farley and Ellis cases. ${ }^{25}$ It

20304 U.S. 458 (1937).

21 "Moreover, a Court of Appeals must, under Johnson v. Zerbst, 304 U.S. 548, afford one who challenges that certification the aid of counsel unless he insists on being his own. ..." United States v. Johnson, 352 U.S. 565, 566 (1957).

${ }^{22}$ See note 2 supra.

${ }^{23}$ See notes 4 and 6 supra.

${ }^{24}$ Section 1915(b) provides that the appellate court may direct the printing of the record on appeal at government expense, but the language is permissive, not mandatory. See Whitt $v$. United States, 259 F.2d 158 (App.D.C., 1958). The courts of appeals have indicated that they are not required by the statute to give every indigent petitioner a free transcript. Cash v. United States, 261 F.2d 731 (App.D.C., 1958), judgment vacated 357 U.S. 219 (1958); United States v. Visconti, 261 F.2d 215 (C.A.2d, 1958); United States v. Stevens, 224 F.2d 866 (C.A.3rd, 1955); United States v. Carter, 88 F.Supp. 88 (D.D.C., 1950). The statement of the Court of Appeals in O'Rourke v. United States, 248 F.2d 812 (C.A.1st, 1957), cert. denied sub. nom. Dewan v. United States, 356 U.S. 922 (1958), is an excellent apology for this view: " 28 U.S.C. $\$ 1915$ does not block hopeless appeals by appellants who are able to bear the costs of appeal. It does, however, serve to protect the appellate courts from being overburdened with frivolous appeals by indigent appellants at public expense. If the appellate court has to examine a lengthy transcript of the evidence, and practically to hear the case on its ultimate merits, in order to determine the preliminary issue now presented to us, obviously the appellate courts would have no protection from being overburdened with frivolous appeals on behalf of indigents at public expense; the limitation on our appellate jurisdiction in 28 U.S.C. $\$ 1915$ might as well be repealed, and these preliminary appeals now before us might as well be abolished as an unnecessary and time-consuming superfluity." Id., at 814. But cf. Montgomery v. Virginia Stage Lines, 184 F.2d 1000 (App.D.C., 1950). See generally note 10 supra.

25 "It is quite clear that Congress, while intending to extend to poor and meritorious suitors the privilege of having their wrongs redressed without the ordinary burdens of litigation, at the same time intended to safeguard members of the public against an abuse of the privilege by evil-minded persons who might avail themselves of the shield of immunity from costs for the purpose of harassing those with whom they were not in accord, by subjecting them to vexations and frivolous legal proceedings." O'Connel v. Mason, 132 Fed. 245, 247 (1904), quoted in Caviness v. Somers, 235 F.2d 455, 456 (C.A.4th, 1956). 89 Cong. Rec. 10871-73 (1943); Hearings Before a Subcommittee of the Committee of the Judiciary on Sen. 620,78th Cong. 1st Sess. 23, 43-5 (1943); Sen. Rep. No. 533, H.R. Rep. Nos. 868, 962, 78th Cong. 1st Sess. (1943). See Cash v. United States, 261 F.2d 731 (App.D.C., 1958), judgment vacated 357 U.S. 219 (1958); United States v. Visconti, 261 F.2d 215 (C.A.2d, 1958); Weber v. United States, 257 F.2d 585 (C.A.8th, 1958), cert. denied 358 U.S. 912 (1958); O'Rourke v. United States, 248 F.2d 812 (C.A.1st, 1957), cert. denied sub. nom. Dewan v. United States, 356 U.S. 922 (1958); United States v. Stevens, 224 F.2d 866 (C.A.5th, 1955); Parsell v. United States, 218 F.2d 232 (C.A.5th, 1955). 
seems fair, therefore, to conclude that the underlying rationale for these cases must be sought outside the ambit of Section 1915 .

Similarly, the view that these cases can be interpreted as resting solely upon the Sixth Amendment must be discarded as overly restrictive. Here again, the position is not altogether unsupportable as evidenced by the citation of Johnson v. Zerbst $t^{26}$ in the Johnson opinion. This is buttressed by the fact that the narrow decision in each of these cases could be explained in Sixth Amendment terms. Thus it could be argued that the right to counsel means the right to effective counsel, and that this includes the right to such incidental aids as transcripts of the trial proceedings which are necessary to effective advocacy. ${ }^{27}$

While this interpretation may explain what the Court did in these three cases, it does not offer an adequate explanation of what the Court said. The language of the Jolnsson opinion clearly treats the requirement of a transcript as independent of the requirement of counsel. Moreover, this expansive interpretation of the Sixth Amendment would not only make the Due Process Clause quite superfluous in this field, but would also introduce a doctrine so novel that it hardly seems credible for the Supreme Court to introduce such an innovation by way of a per curiam memorandum.

This discussion, though casting doubts upon a rationale of the Johnson, Farley and Ellis decisions based solely upon statutory or Sixth Amendment grounds, should not be taken as implying that such considerations are totally irrelevant. Rather, the discussion is intended to show that broader grounds of interpretation seem required in order to provide full understanding of these cases. It now must be determined which of the two broader grounds of interpre-

${ }^{26} 304$ U.S. 458 (1937).

${ }^{27}$ In this context, the statement by the Supreme Court in the Ellis case that the indigent must be represented by an "advocate" rather than an "amicus," would be a related amplification of the Sixth Amendment right to counsel. See Indigent Defendant-Appeal from Conviction-Duty of Court-Appointed Counsel, 4 Wayne L. Rev. 245 (1958); Criminal ProcedureAppeal in Forma Pauperis-Appointed Counsel Need Not Present Full Oral Argument in Providing Adequate Representation for Appellant, 33 Notre Dame Lawyer 4 (1958); cf. Aid for Indigent Litigants in the Federal Courts, 58 Col. L. Rev. 832, 849 (1958). However, it would be difficult to include the equally important rule in the Ellis case-that leave to appeal in formo pauperis must be granted if the indigent presents allegations which are not plainly frivolous-with any type of Sixth Amendment guaranty, although this rule might be related to sub-section (d) of 28 U.S.C.A. \$1915 (1954): "The court may request an attorney to represent any such person unable to employ counsel and may dismiss the case if the allegation of poverty is untrue, or if satisfied that the action is frivolous or malicious." Furthermore, at the trial level, "effective counsel" has never been broadened in such a manner. The attorney need not be compensated or reimbursed for his expenses. See Cross, "The Assistance of Counsel for his Defense": Is This Becoming a Meaningless Guarantee?, 38 A.B.A.J. 995 (1952); The Right to Benefit of Counsel Under the Federal Constitution, 42 Col. L. Rev. 271 (1942); Jacoby, Legal Aid to the Poor, 53 Harv. L. Rev. 940 (1940). Under Fed. Rule 17(b) the trial court has discretion to summon witnesses at government expense. This situation may be changing with the move to establish a public defender in the federal courts. Sen. 3,275, 85th Cong. 2d Sess. (1958). See United States ex rel. Smith v. Baldi, 344 U.S. 561, 568 (1953). 
tation, i.e., fair appellate hearing or equality of treatment, supplies the most cogent explanation of these decisions. ${ }^{28}$

\section{III}

The constitutional concepts underlying federal treatment of indigent appeals are closely related to state treatment of similar situations. Although the Fifth Amendment contains no Equal Protection Clause, recent decisions tend to indicate that the limitations imposed upon federal courts by the Fifth Amendment are no less severe than those imposed upon the states by the Fourteenth Amendment. ${ }^{29}$ Consequently, the interpretation to be placed upon the Johnson, Farley; and Ellis decisions depends, in large part, upon the interpretation given to the Court's earlier opinion in Griffin v. Illinois, ${ }^{30}$ a case involving the constitutionality of state indigent appeal procedures. The issue in the Griffin case was the validity of Illinois post-conviction procedure which required a transcript as a prerequisite to appeal, ${ }^{31}$ yet granted free transcripts to indigents only in capital cases ${ }^{32}$ or where constitutional errors were alleged. ${ }^{33}$ This procedure resulted in precluding appellate review in non-capital cases to indigents who merely claimed nonconstitutional trial errors. ${ }^{34}$

In delivering the judgment of the Supreme Court whereby this procedure was invalidated, Mr. Justice Black declared that the guaranties of both the Due Process and Equal Protection Clauses of the Fourteenth Amendment were violated, ${ }^{35}$ without, however, differentiating between their respective functions in this case. Since considerable uncertainty results from this omission, it is necessary to inquire into the cases following Griffin to determine the true meaning of that case.

${ }^{28}$ Although there is no constitutional requirement of appellate review, McKane v. Durston, 153 U.S. 684, 687-88 (1894), nevertheless once such review is established, it is subject to due process and equal protection guarantees. Griffin v. Illinois, 351 U.S. 12, 18 (1956); Dowd v. United States ex rel. Cook, 340 U.S. 206, 208 (1951); Cole v. Arkansas, 333 U.S. 196, 201 (1948); Cochran v. Kansas, 316 U.S. 255, 257 (1942); Frank v. Mangum, 237 U.S. 309,327 (1915). These doctrines would tend to cast doubt upon the lower courts which have distinguished the Johnson, Farley and Ellis cases because they are only statutory or Sixth Amendment cases, inapplicable to other post-conviction procedures. See cases cited in note 8 supra. If these cases derive from broader grounds than the statute or the Sixth Amendment, it would seem that their principles would extend to all forms of post-conviction procedures.

29 "While due process under the Fifth Amendment, as under the Fourteenth, does not require appellate review, nevertheless when Congress creates that right it is not free from all constitutional restrictions, including the obligation not to make unreasonable discriminations." Boykin v. Huff, 121 F.2d 865, 872 (App.D.C., 1941). See Bolling v. Sharpe, 347 U.S. 497, 500 (1954); Hurd v. Hodge, 344 U.S. 24, 35 (1948). But cf. United States v. Sanders, 142 F.Supp. 638, 645 (D.Md., 1956).

${ }^{30} 351$ U.S. 12 (1956). ${ }^{31}$ Ill. Rev. Stat. (1957) c. 110, \$101.65.

s2 Ill. Rev. Stat. (1957) c. 38, \$769a.

33 Ill. Rev. Stat. (1957) c. 38, \$826-32.

${ }^{34}$ See Griffin v. Illinois, 351 U.S. 12, 14n. 4 (1956). $\quad{ }^{35} \mathrm{Id}$., at 18. 
Eskridge v. Washington Prison Board ${ }^{36}$ is the most significant Supreme Court decision, for present purposes, involving the application of the Griffin case to state post-conviction procedures. This case involved the denial by the state of Washington of leave to appeal in forma pauperis in the state courts under a statute similar to Section 1915. The statute provided that the trial judge could order a transcript of the trial for the indigent if the judge thought that justice would thereby be promoted. ${ }^{37}$ The transcript was a prerequisite to appeal.

The Washington statute may be distinguished from the Illinois procedure invalidated in the Griffin case. Whereas Illinois flatly prohibited indigent appeals in all but a limited category of cases, Washington permitted any indigent to appeal, subject to the power of the trial judge to sift out useless appeals.

The Supreme Court, however, was unimpressed by this possible ground of distinction. In reversing a denial of a petition for habeas corpus, the Court, speaking only through a per curiam memorandum, held that Griffin was controlling. In doing so, the Court pointed out that the guaranties of the Fourteenth Amendment (without specification) required states to provide appellate review for indigents if such review was made available to nonindigents, and then continued with the following remarks:

The conclusion of the trial judge that there was no reversible error in the trial cannot be an adequate substitute for the right to full appellate review available to all defendants in Washington who can afford the expense of a transcript. We do not hold that a State must furnish a transcript in every case involving an indigent defendant. But here, as in the Grifin case, we do hold that, '[d]estitute defendants must be afforded as adequate appellate review as defendants who have money enough to buy transcripts. ..." " (Italics added.) $)^{38}$

Although the Court's language is not without ambiguity, its general thrust seems clearly to be that the Washington procedure was wrong because it imposed a burden upon indigents which was not placed upon nonindigents. And the citation of Griffin seems to indicate that the Court regards that case as requiring that indigents and nonindigents be treated alike insofar as appellate review of criminal convictions is concerned. Thus the language of the Eskridge case seems to interpret Grifin as resting primarily upon equal protection grounds. Moreover, this conclusion is reinforced by the fact that the Court gave no consideration at all to the effect of the Washington sifting process. Rather, it treated the mere existence of a sifting process as sufficient to invalidate a state's procedure.

Thus the decision in the Eskridge case seems dispositive of the questions of the interpretation of the Griffin case, and would seem to control the Johnson, Farley and Ellis cases because of the similarity of the procedures involved. ${ }^{39}$ The law rather clearly seems to be that no classification based upon poverty

\footnotetext{
36357 U.S. 214 (1958). ${ }^{37}$ Rev. Code Wash. (1951) § 2.32.240.

${ }^{38} 357$ U.S. 214, 216 (1958).

${ }^{39}$ Compare text at note 10 supra, with text at note 37 supra.
} 
will be allowed where its effect is to create a disparity between indigents and nonindigents in the availability of review of criminal convictions. It is doubted, however, that such a rule is well-advised.

An invalid classification analysis of the Johnson, Farley and Ellis cases would seem to lead to the conclusion that any special treatment of indigent appellants imposed by Section 1915 must be unconstitutional. The alternative to this view is a due process or fair hearing analysis. The theory in this analysis is that the denial of a transcript or counsel to the indigent appellant is unconstitutional, not because there is no similar deprivation in the case of nonindigent appellants, but because it deprives the indigent of his chance to present to the appellate court what may be a valid objection to his conviction. ${ }^{40}$ Under this view, a sifting process which precludes only frivolous appeals would be permissible so long as it did not operate to bar meritorious appeals from being heard by the appellate courts. The Johnson, Farley and Ellis cases can here be understood as holding that the practice of the federal courts of withholding transcripts from indigents until they had proved the merit of their appeals denied them any effective opportunity of gaining appellate review. ${ }^{\text {al }}$

It may be argued that the invalid classification rationale obliquely sanctioned in the Eskridge case is untenable. A classification based upon the ability to pay may be reasonable and useful in the area of criminal appeals. Statutes such as Section 1915 seem designed to produce a reduction in the quantity of frivolous appeals which needlessly consume the time of the appellate courts. ${ }^{42}$ Since nonindigent appeals are subject to dismissal if they are

40 "For the point is not so much that the defendant is being 'discriminated' against by virtue of the fact that the man of means is reaping certain of the advantages of having money. The question is, rather, whether the state can reasonably be required to take certain particular measures in order to minimize the perils of convicting the innocent or depriving a man of liberty who has a good legal defense." Allen, The Supreme Court and State Criminal Justice, 4 Wayne L. Rev. 191, 199 (1958).

${ }^{11}$ See note 15 supra. The mere fact that Section 1915 erects a sifting process for screening out frivolous appeals would not in itself constitute a violation of due process. However, if the federal courts so abused the latitude allowed by the statute for such filtration so that no appeals of indigents - meritorious or frivolous-could be heard, then federal procedure would fall afoul of the Due Process Clause of the Fifth Amendment. At the stage where indigents were effectively excluded from appellate review, federal procedure becomes identical with the procedure followed in Illinois prior to Griffin v. Illinois, 351 U.S. 12 (1956), and subject to the same crilicisms that were levied against Mlinois.

42 The courts have pointed out that legitimate ends are served by screening indigent appeals: (1) avoiding unnecessary expenditure of public funds, Cash v. United States, 261 F.2d 731 (App.D.C., 1958), judgment vacated 357 U.S. 219 (1958); United States ex rel. Farnsworth v. Murphy, 254 F.2d 438 (C.A.2d, 1958), judgment vacated 358 U.S. 48 (1958); Caviness v. Somers, 235 F.2d 455 (C.A.4th, 1956); (2) avoiding the overcrowding of appellate dockets by the presence of too many frivolous appeals to the detriment of more worthwhile appeals, O'Rourke v. United States, 248 F.2d 812 (C.A.1st, 1957), cert. denied sub. nom. Dewan v. United States, 356 U.S. 922 (1958); United States v. Johnson, 238 F.2d 565 (C.A.2d, 1956), judgment vacated 352 U.S. 565 (1957); (3) avoiding harassment of public officials who must resist such appeals, Caviness v. Somers, 235 F.2d 455 (C.A.4th, 1956); Parsell v. United States, 218 F.2d 232 (C.A.5th, 1955); Higgins v. Steele, 195 F.2d 366 (C.A.8th, 1952). Section 
frivolous, no special burdens appear to be placed upon indigents as a class by some requirement of merit. ${ }^{43}$

The fact that an indigent is required to go through a sifting process as a prerequisite to perfecting his appeal does not seem per se unfair. If the objection to the sifting process is merely that it imposes added inconveniences upon indigents, the objection would not seem persuasive since such an imposition would be equivalent to the inconvenience in the form of financial expense imposed upon nonindigents. ${ }^{44}$ Such a cost factor may well operate to prevent the appearance of many frivolous appeals without, however, substantially deterring meritorious appeals. ${ }^{45} \mathrm{~A}$ sifting process for indigent appeals could well operated in the same manner.

If, on the other hand, the objection to a particular sifting process is that it operates to preclude meritorous appeals as well as frivolous appeals, the process would seem more properly attacked on the basis of fairness rather than in terms of inequality of treatment. ${ }^{46}$ The vice of such a process is not that it singles out indigents for special treatment, but that in singling them out it denies them the opportunity to secure adequate review of their convictions. The denial of counsel and transcripts to indigents seeking to appeal would be con-. demned only insofar as such a denial deprives indigents of their chance for a fair appellate hearing.

1915 aims only at the reduction of indigent appeals, and it is the view of the federal courts that indigents are the source of most frivolous appeals. Caviness v. Somers, 235 F.2d 455 (C.A.4th, 1956). If the major threat to efficient judicial administration comes from this one group, Congress can legislate specifically to cure this evil. Wiliamson v. Lee Optical Co., 348 U.S. 4833 , 489 (1955).

${ }^{43}$ Fed. Rules Crim. Proc. 39(a) provides in part, "The appellate court may at any time entertain a motion to dismiss the appeal. ..."

44 See Willcox, Karlen and Roemer, Justice Lost-By What Appellate Papers Cost, 33 N.Y.U. L. Rev. 934, 936 (1958).

${ }^{45}$ In this context it should be remembered that indigents are the only class allowed to appeal without payment of costs. Probably even more significant than the waiver of costs is the fact that free legal services are usually provided to the indigent allowed to appeal. See Morris v. United States, 248 F.2d 618 (App.D.C., 1957), cert. denied 357 U.S. 929 (1958). But see Aid for Indigent Litigants in the Federal Courts, 58 Col. L. Rev. 832, 850-51 (1958). Thus any burden of merit imposed upon indigents is partly offset by the benefit of no costs, while any benefit of waiver of proof of merit redounding to nonindigents is partly offset by the burden of costs imposed upon them.

${ }^{46}$ The denial of appellate review in circumstances where such review is available is equivalent to judgment against a party without giving him the opportunity to speak in his defense. Price v. Johnson, 334 U.S. 266, 280 (1948); Cole v. Arkansas, 333 U.S. 196, 202 (1948); Foster v. Illinois, 332 U.S. 134, 137 (1947). See Slochower v. Board of Education, 350 U.S. 551, 559 (1956); Rochin v. California, 342 U.S. 165, 172 (1952); Snyder v. Massachusetts, 291 U.S. 97, 105, 108 (1934); Traux v. Corrigan, 257 U.S. 312, 332 (1921); Twining v. New Jersey, 211 U.S. 78, 111 (1908); Hovey v. Elliot, 167 U.S. 409, 414, 417 (1897). Judgment without a hearing prevents a party from the presentation of any good defenses he might have and so deprives him of due process of law. Joint Anti-Fascist Refugee Committee v. McGrath, 341 U.S. 123, 162, 171-72, 178, 186 (1951); Wiliiams v. New York, 337 U.S. 241, 245 (1949); Shelley v. Kraemer, 334 U.S. 1, 16 (1948); In re Oliver, 333 U.S. 257, 273-75 (1948); Griffin v. Griffin, 327 U.S. 220, 228 (1946). 
Admittedly, the invalid classification rationale has much to commend it in terms of simplicity. It can be applied almost mechanically and does not involve close attention to the facts of a particular case. But too high a price may be paid for this benefit. The number of indigent appeals is already high and the recent trend of decisions may result in a serious increase. ${ }^{47}$ In the present state of uncertainty generated by the Johnson, Farley, Ellis and Eskridge cases, lower courts, both federal and state, may be too unwilling to exercise discretion in denying leave to appeal in forma pauperis. To the degree that some sifting process seems required to counter the absence of financial restraint on indigent appeals, such a situation is not desirable. The result may be an increase in the cost of judicial administration out of proportion to the benefits conferred.

Clarification by the Supreme Court in this field thus seems/imperative. It is hoped that such clarification will follow due process rather than equal protection doctrines. The Johnson, Farley and Ellis decisions may be explained in those terms, ${ }^{48}$ and the Griffin and Eskridge cases would seem to be similarly under-

${ }^{47}$ See, e.g., the dissenting opinion of Prettyman, C.J., in Surratt v. United States, 262 F.2d 691, 692 (App.D.C., 1958).

${ }^{48}$ Indeed, were these cases to be understood as invalidating any classification of indigents it would be difficult to understand how the Supreme Court could avoid declaring that Section 1915 is unconstitutional insofar as it is the source of such classification. The fact that the Supreme Court instead undertook to order certain correctives to existing federal procedure under the statute argues in favor of an interpretation of these cases in terms of a fair hearing. Thus it can be said that prior federal procedure deprived indigents of a fair hearing insofar as it imposed standards upon them which they could not possibly meet due to their impoverished condition. The Johnson and Farley cases thus improved the condition of the indigent by giving him a transcript before he was expected to meet the standards necessary for an appeal in forma pauperis; the Ellis case, on the other hand, lowered the standards of judging petitions for appeals in forma pauperis by declaring that if the allegations were not plainly frivolous, the appeal must be allowed.

Either corrective would seem sufficient to restore the opportunity for a fair hearing to the indigent to prove any valid claims he may have. It would thus appear that utilization of the two correctives simultaneously would be unwise. The grant of a transcript at public expense is uneconomical if the indigent need only make allegations which are not plainly frivolous. See Cash v. United States, 261 F.2d 731 (App.D.C., 1958), judgment vacated 357 U.S. 219 (1958); O'Rourke v. United States, 248 F.2d 812 (C.A.1st, 1957), cert. denied sub. nom. Dewan v. United States, 356 U.S. 922 (1958). Conversely, if the indigent has already been given a free transcript, he would be put into a better position than the nonindigent if he is judged by the siandards of Rule 39(a) just as the nonindigent is, even though the nonindigent must pay for the probability of a successful appeal. Application of Dinerstein, 258 F.2d 609 (C.A.9th, 1958); Anderson v. Heinze, 258 F.2d 479 (C.A.9th, 1958), cert. denied 358 U.S. 889 (1958); In re Woods, 249 F.2d 614 (C.A.9th, 1957), cert. denied 356 U.S. 921 (1958); Young v. United States, 246 F.2d 901 (C.A.8th, 1957), cert. denied 355 U.S. 917 (1958); Jaffe v. United States, 246 F.2d 760 (C.A.2d, 195'); cf. St. Lawrence v. Clemmer, 260 F.2d 470 (C.A.4th, 1958); United States ex rel. Lowery v. Murphy, 245 F.2d 751 (C.A.2d, 1957).

The choice of remedy should, perhaps, be left to the appellate court which can select according to the exigencies of the particular situation, since a transcript allegedly has no function in some instances. See St. Lawrence v. Clemmer, 260 F.2d 470 (C.A.4th, 1958); Edwards v. United States, 256 F.2d 885 (App.D.C., 1958); Bistram v. United States, 248 F.2d 343 (C.A. 8th, 1957); United States v. Stevens, 224 F.2d 866 (C.A.3rd, 1955); cf. United States v. Hines, 148 F.Supp. 73 (E.D.N.Y., 1957); Application of Pruitt, 119 F.Supp. 737 (W.D.S.C., 1954); United States v. Carter, 88 F.Supp. 88 (D.D.C., 1950); United States v. Hoskins, 85 F.Supp. 313 (E.D.Ky., 1949). But see note 6 supra. 
standable on their facts. ${ }^{49}$ Thus the Court is not yet irrevocably committed to an equal protection rationale. A full dress opinion by the Supreme Court embodying a due process rationale would not only avert needless increases in the cost of judicial administration, but would also enable the courts, state and federal, ${ }^{50}$ to establish procedures which would allow meritorious indigent appeals to be heard while dispensing with those which are frivolous.

${ }^{49}$ There is language in Griffin which is readily applicable to a due process interpretation of that case: "Surely no one would contend that either a State or the Federal Government could constitutionally provide that defendants unable to pay court costs in advance should be denied the right to plead not guilty or to defend themselves in court. Such a law would make the constitutional promise of a fair trial a worthless thing. Notice, the right to be heard, and the right to counsel would under such circumstances be meaningless promises to the poor. . . There is no meaningful distinction between a rule which would deny the poor the right to defend themselves in a trial court and one which effectively denies the poor and adequate appellate review accorded to all who have money enough to pay the costs in advance." Griffin v. Illinois, 351 U.S. 12, 17-18 (1956).

${ }^{50}$ The Supreme Court has power to balance these interests in the federal courts by virtue of its authority under the Criminal Appeals Rules Act, 62 Stat. 846 (1948), as amended, 18 U.S.C.A. $\$ 3771$ (1958). Since this general regulatory power does not extend to state procedures, it is likely that federal courts will be held to stricter standards than are state courts in in forma pauperis proceedings.

\section{FOREIGN DONEE'S WIL: REQUIREMENT OF PROBATE AT DONOR'S DOMICILE}

When, after a foreign donee's ${ }^{1}$ testamentary exercise of a power of appointment granted by a domiciliary donor, a trustee is faced with the duty of disposing with the corpus of a trust, two competing rules of law often appear to frustrate the trustee's attempt to determine the validity of the donee's exercise of the power. ${ }^{2}$ Courts in a majority of jurisdictions, in the absence of any clear expression of intention by the donor, will construe a donor's will granting a power of appointment "exercisable by will"' to require that the donee's instru-

${ }^{1}$ As used herein the term "donee" refers to a donee who neither is domiciled nor has property, other than the power of appointment if the power should be deemed property, in the donor's domicile.

${ }^{2}$ It is clear that where both the trustee and the property subject to appointment are located at the donor's domicile the courts of that state can make an independent determination as to whether the powers have been validly exercised, and may completely disregard the decrees of the donee's domicile concerning the donee's will in so far as such decrees purport to determine the validity and effect of the attempted exercise of the powers. Blount v. Walker, 134 U.S. 607 (1890); In re Harriman's Estate, 124 Misc. 320, 208 N.Y.S. 672 (Surr.Ct., 1924). See also Mulford, The Conflict of Laws and Powers of Appointment, 87 U. of Pa. L. Rev. 403, 418-19 (1939).

3 This comment is concerned only with those grants of powers wherein the donor specifies neither a particular statute of wills with which the donee's instrument must comply nor whether the donee's instrument must be probated to effectively exercise the power. The language usually employed is "as [the donee] shall by will appoint" [Wachovia Trust Co. v. Doughton, 272 U.S. 567, 572 (1926)], "by her last will and testament in writing" [Sewall v. Wilmer, 132 Mass. 131, 132 (1882)], or, "as per his last will and testament" [In re Sloan's Estate, 7 Cal.App.2d 319, 321, 46 P.2d 1007, 1008 (1935)]. 